\title{
ACRL in Chicago ACRL programs at the ALA Annual Conference
}

A LA's 132st Annual Conference was held June 27-July 2, 2013, in Chicago. Approximately 26,362 librarians, library support staff, exhibitors, writers, educators, publishers, and special guests attended the conference. Ed. note: Thanks to the ACRL members who summarized programs to make this report possible.

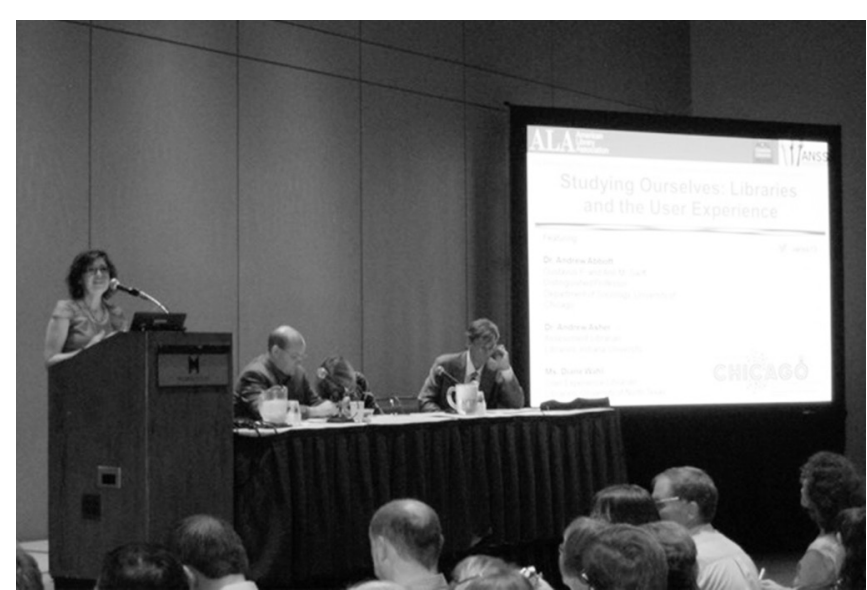

Speakers at the Anthropology and Sociology Section program.
They don't know how they actually find information. Their use of materials, skills, and questions interact to redefine the question. He observed that undergraduates are quite good at finding things, but not at understanding what to ignore.

Andrew Asher gave an overview of how ethnographic studies give a holistic view of how libraries are used. The ERIAL project (erialproject.org) used interviews, observations, visualization (photojournals), and mapping of time use and location to study how students find and use information for assignments.

Asher outlined reasons for using ethnographic research, including empirical examples are very persuasive, "data about 'our' students is hard to ignore," and it is useful in building relationships with faculty. Their study lead to an increase in requests for instruction, in-

\section{Studying ourselves}

"Studying Ourselves: Libraries and the User Experience," sponsored by the Anthropology and Sociology Section in collaboration with the University Library Section, gave an overview of ethnographic research and how it has been used in libraries. Andrew Abbott discussed his research focusing on "real" use of a large academic collection. "Scholars don't use the library the way librarians think they do or even as they think they should."

He explained that experts don't come to the library with clearly defined problems. creased emphasis on research consultation, and better information for administrators to use to make the case for the library.

Diane Wahl discussed the issues of doing studies at her institution, particularly with distance students. Issues included recruiting for the study, challenges in scheduling, and technology issues. She emphasized the need to include all stakeholders to involve them in creating solutions to problems identified. She ended by challenging librarians to do additional study of the issues of nontraditional students and figuring out how we can help 
with student retention by better meeting their needs. You can continue the conversation and get links to more information at http:// annssacrl.wordpress.com/conference/2013 -chicago/program/._Beth Fuseler Avery, University of North Texas, beth.avery@unt.edu

\section{Value enhanced}

"Value Enhanced: Reimagining a Philosophy of Excellence," the College Libraries Section program, featured four past recipients of the ACRL Excellence in Academic Libraries Award in the college category. After winning the award, these library leaders continued their dedication to excellence through new endeavors, described during the program.

Ann Zawistoski of Carleton College (2008 winner) described an assessment initiative that began internally but developed into par-
Diane Graves of Trinity University (2007 winner) launched an open access policy and institutional repository, using persuasive outreach initiatives to convince faculty members that open access benefits them and their scholarship.

The experiences of more winning libraries may be found in the newly released Excellence in the Stacks: Strategies, Practices and Reflections of Award-winning Libraries (Chandos, 2013), coedited by Susan Swords Steffen and Jacob Hill._-Jane P. Currie, Loyola University, jcurrie@luc.edu

\section{Assessing online instruction}

"Is it worth it? Assessing online instruction," the Distance Learning Section program cosponsored by the Community and Junior College Libraries Section and the Instruction Section, was a panel ticipation in campus-wide assessment of student research and writing. This collaboration has resulted in an appreciation among faculty members and administrators for the important contribution librarians can make to institutional assessment.

Carla Tracy of Augustana College (2006 winner) led a re-envisioning of collections and spaces that is putting the library at the center of student services and activities. She credits the library's proven

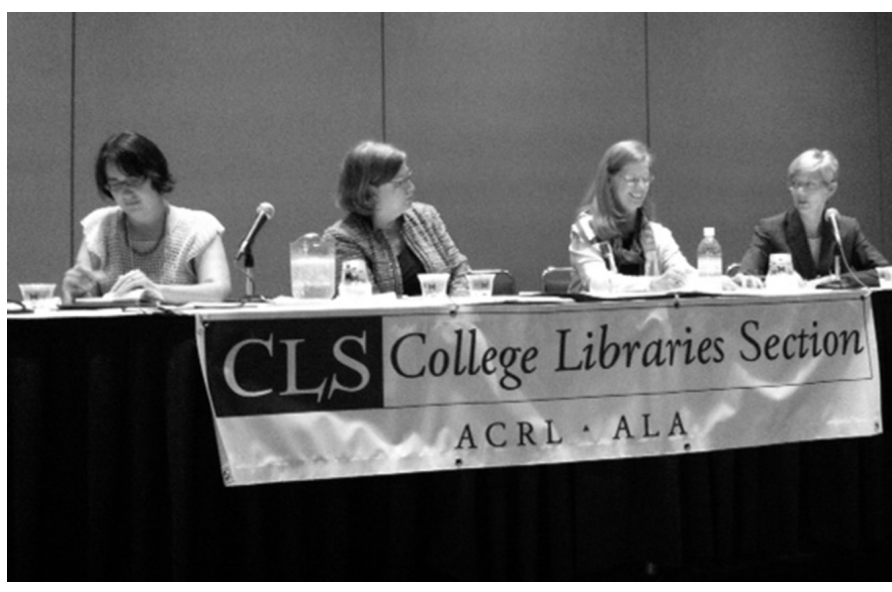

Pictured (left to right) from the College Libraries Section program are Ann Zawistoski, Carleton College; Carla Tracy, Augustana College; Janet Cottrell, Champlain College; and Diane Graves, Trinity University. dedication to excellence with helping overcome potential opposition to the smaller but more relevant collection among faculty and other stakeholders.

Janet Cottrell of Champlain College (2012 winner) experienced rapid changes after winning the award, both among her staff and in the place for information literacy in the core curriculum. Commitment to excellence continued, emphasizing the library as "radically pragmatic," characterized by staff and services that are "resilient and reflective." discussion moderated by Katy Kavanagh (East Carolina University). The panel featured three librarians who currently engage in various forms of online instruction. Panelists responded to a series of questions addressing the development and use of learning outcomes in assessment, designing summative and formative assessments, and gathering data to align online instruction with institutional learning outcomes. These questions were followed by an audience-driven question-and-answer session. 
Each panelist began the dialogue by describing his or her experience with online instruction. Panelist Carol McCulley (Linfield College) discussed her focus on studentcentered learning and on using authentic assignments to help build student confidence and a sense of community within the class. Andrew Todd and Tim Botorff (both from the University of Central Florida) summarized the findings of their 2012 article that reviewed the current state of assessment in online learning and shared how their research has helped them each develop robust embedded librarianship programs on their campuses.

The panelists agreed that using a mix of assessment types and technologies is essential to measure student learning accurately, and to help inform changes to instructional ma-

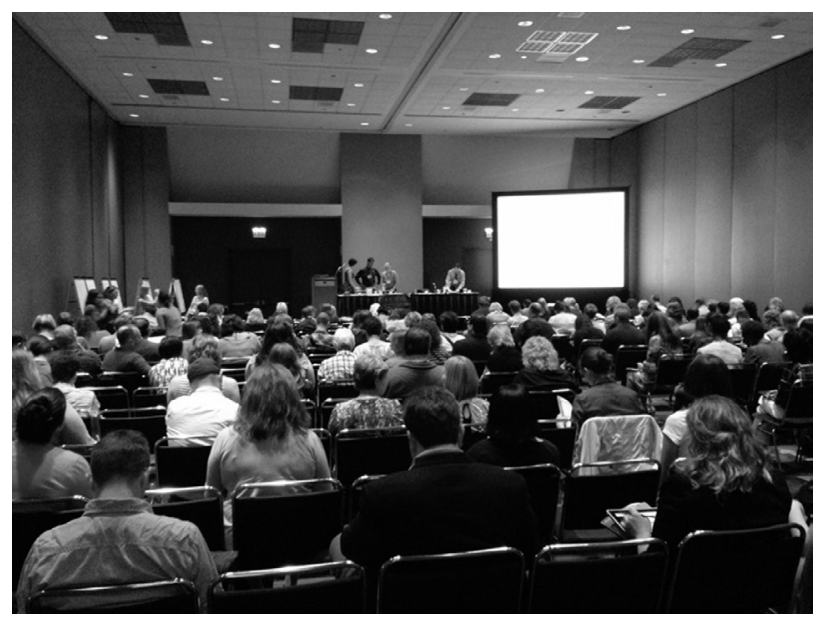

A full house attended the Distance Learning Section program, cosponsored by the Community and Junior College Libraries Section and the Instruction Section, on assessing online instruction. terials. Methods

of assessment used by the panelists include automated quizzes, open-ended assignments, annotated bibliographies, surveys, online discussions, and assignment specific rubrics. Another recurring theme of the panel was the need to communicate frequently with faculty and to develop learning outcomes that align to class goals.

Panelists mentioned a variety of helpful resources, including the University of Iowa's Library Instruction Assessment Toolkit, Debra Gilchrist's work, and Megan Oakleaf's research. More information on the panel with additional resources can be found at http://connect.ala. org/node/203622._Carrie Moran, University of Central Florida, carrie.moran@ucf.edu

\section{Crossing the $\mathrm{K}-20$ continuum}

The Education and Behavioral Sciences Section-sponsored program hosted a panel with information literacy expert Kenneth Burhanna, assistant dean for engagement and outreach at Kent State University Libraries and editor of Informed Transitions: Libraries Supporting the High School to College Transition (ABC-CLIO, 2013), and Google Search Educator Tasha Bergson-Michelson, organizer of Google's Creating Professional Development about Search online community. The panelists discussed their experiences from their respective teaching environments about how they help students cross the K-20 continuum.

Burhanna presented "Battling the Unready: Zombies, Einstein and Libraries." His discussion cleverly connected how graduating high school "zombie" students may not be prepared for college-level work and how academic and school librarians work to piece together their preparation and eventual success. Burhanna introduced sample case studies that showcase collaboration across the continuum from his book.

Bergson-Michelson highlighted much of her curricular goals for teacher librarian professional development that ultimately empowers student searchers. BergsonMichelson's community of practice includes about 300 educators who learn to teach their students how to search more efficiently.

The Google Search Educator site was shared with attendees so that they might use 
or adapt many of the teaching materials and lesson plans, many of which have been mapped to various standards of learning.

Burhanna's presentation slides can be found at www.slideshare.net/kburhanna /battling-the-unready. Bergson-Michelson's presentation materials can be found at http://bit.ly/SearchSources.-Alex $R$. Hodges, American University (DC), hodges @american.edu

\section{There's an app for that}

The Science and Technology Section cosponsored a program with the Instruction Section and the Health Sciences Interest Group titled "There's an App for That: The Use of Mobile Devices, Apps and Resources for Health and Sci-Tech Librarians and Their Users." The three panelists were Max Anderson (Rush University Medical Center); Emily J. Hurst (National Network of Libraries of Medicine, South Central Region); and Rebecca K. Miller (Virginia Tech University Libraries).

Anderson presented a program on "Starting an iPad program in a Medical College." He discussed the program at Rush University and said that several medical schools were already involved in iPad programs, including the University of California-Irvine. All new medical students at Rush will receive iPads, and Rush will need to expand security measures during the second year, especially regarding accessing medical records. Anderson also described the apps that medical students use in their courses.

Hurst explained the mobile applications that are available from the National Library of Medicine (NLM). People can develop their own apps from NLM's resources. She also said that people should remember that not all apps will fit on all devices or platforms. Hurst added that people using tablets must consider the required accessories and environments (such as using tablets in a sterile environment).

Miller discussed the history of mobile technology (dating back to 1968), as well as the growth and popularity of mobile devices. Student ownership and use of mobile devices has been steadily increasing, and mobile technology affects what we teach in libraries (information literacy skills) and how we teach (using technology as a collaboration tool in the classroom).

The slides for the presentation are available at www.slideshare.net/maxlibris/ala -2013. Additional resources are available at http://stsmobileapps.tumblr.com/._Edward Kownslar, Texas AEM University-Corpus Christi, edward.kownslar@tamucc.edu

\section{Print principles in a digital world}

The ACRL Intellectual Freedom Committee sponsored "Print Principles in a Digital World: Intellectual Freedom in the 21st Century Academic Library" with Doug Archer (University of Notre Dame) and Martin Garnar (Regis University). Using concepts from Intellectual Freedom Principles for Academic Libraries: An Interpretation of the Library Bill of Rights and a list of concerns under study by the Digital Content Working Group's subgroup on Privacy and Ethics (of which Archer and Garnar are both members), the speakers set the context for small group discussions with assigned questions.

Representative questions include "What are the implications for reader privacy and uninhibited inquiry if third party vendors gain access to personally identifiable information?" and "As we transition from gatekeepers to educators and guides, how can we model ethical use of information?" After a short discussion period, participants were invited to the microphones to share what was said in their groups.

Comments from participants included: Moving from stacks to seats and from individual to group work may provide opportunity to educate for intellectual freedom. Reader privacy and uninhibited inquiry go together. False assumptions can be made from one's research patterns. Third party access to personal information undermines reader privacy. Do we have an ethical duty to educate users on privacy tradeoffs? Reliance on search engine algorithms means a loss of control of the search process. The academy 
loses historical data in continually updated reference sources. The loss of historical context may be lost if variant editions are not archived. Choosing to archive "significant" content begs the questions "What is significant and who decides?" Knowledge can no longer be containerized. Cross silo neural networking is an emerging model. The Big Brother threat means that changes in content can be made intentionally or accidentally or for commercial purposes with no checks or controls.-Martin Garnar, Regis University, mgarnar@regis.edu; Doug Archer, University of Notre Dame, archer.1@nd.edu

\section{Why intellectual freedom matters to academic libraries}

The Intellectual Freedom Committee sponsored a session entitled "Why Intellectual Freedom Matters to Academic Libraries." The featured speaker was Barbara Jones, director of the ALA Office of Intellectual Freedom and executive director of the Freedom to Read Foundation. Jones discussed such issues as freedom of speech, the First Amendment, balanced collections, books by authors later tarnished, campus privacy rules, recent lawsuits brought against librarians, faculty academic freedom, and student academic freedom. Jones also spoke to activities within the ALA Office of Intellectual Freedom involving academic libraries, most notably the threats of lawsuits against several librarian bloggers for expressing professional opinions and assessments. Jones closed the session by providing numerous useful references and resources such as Web sites (privacy. org), books (Priests of democracy, Unlearning library, Protecting intellectual freedom in your academic library), events (National Constitution Day, September 17), and centers (First Amendment Center).

Questions and answers followed, one of which informed librarians about how they could get involved in intellectual freedom-related initiatives throughout the organization, such as by joining the Intellectual Freedom Round Table, a division Intellectual Freedom Committee, and more.-Theresa Liedtka,
University of Tennessee-Chattanooga, theresaliedtka@utc.edu

\section{Bringing the Immersion Program back home}

The ACRL Immersion Program Committee hosted "Bringing the Immersion Program Back Home," a panel discussion and poster session in which 35 attendees heard the firsthand experiences of four Immersion Program alumni panelists and how each implemented concepts they learned while participating in an Immersion Program.

Jennifer Kelley (College of DuPage) began her career in 2006 with no instruction experience. In 2007, she was quickly immersed in learning theories during the teacher track of the Immersion Program. Since Immersion, Kelley has been tasked with building an information literacy program at her institution.

Another panelist, Jessica Knoch (Grant MacEwan University), described how she used tools learned in the assessment track to transform a large-scale information literacy program that previously had no formal assessment plan within weeks of returning from Immersion.

Tahirah Akbar-Williams's (John Hopkins University) Immersion experience gave her the opportunity to connect and collaborate with colleagues. "Immersion was the opportunity for us to be able to play and be creative using the concepts we learned." After Immersion, Akbar-Williams developed a required online course module, Introduction to Research, which is now being implemented for all Education students this fall.

The fourth panelist, Rebecca Miller, completed the 2011 teacher and 2012 program tracks of the Immersion Program. Her goal was to bring back the Immersion experience for her colleagues by creating a "community of practice" among the instruction librarians as well as other librarians at Virginia Tech.

After the panel presentation, attendees asked questions and had the opportunity to review and discuss five posters presented 
by Immersion Program alumni._Bethany Tschaepe, Prairie View A\&M University, bethany.tschaepe@gmail.com

\section{Tips for teaching the one-shot library instruction session}

Sponsored by ACRL and based on an article authored by the six presenters, this program began with an a capella version of "Moon and six to introduce lesson plans and needs assessments as solid tools for organized and appropriately paced instruction sessions. Tips six and seven, presented by Oakleaf and Hensley, promoted active learning and instructor enthusiasm as antidotes to student apathy and teacher burnout.

Tips eight, nine, and ten-presented by Michelle Millet (John Carroll University) and

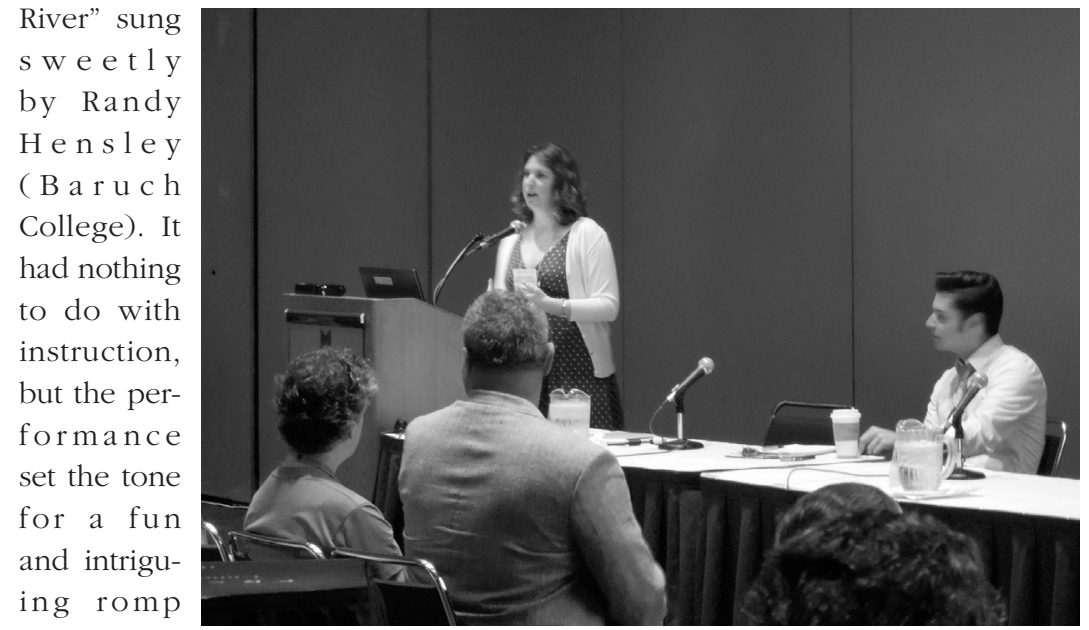

th roug h

"Lessons for

the librarian: Ten tips for teaching the one-shot library instruction session."

Tip one was presented by Steven Hoover (Syracuse University). He argued that "all it takes to fail in library instruction is to not make any choices. By not making choices, you have chosen to fail." Spend class time on content students absolutely must know, and relegate material worth being familiar with to research guides. Tip two, presented by Beth Woodard (University of Illinois at Urbana-Champaign), encouraged librarians to be well-versed in the instructional needs of those with learning styles other than your own in order to design classes that engage all learners. Tip four, presented by Megan Oakleaf (Syracuse University), advocated for assessment: "the core of teaching is to know if your students are learning. If you do not assess, you will never know." Jennifer Corbin (Tulane University) used tips five
Hoovercan be synthe sized into a single charge for using oneshot instruction as a chance to build strong relationships with faculty and other campus partners in order to integrate information literacy into curricula and align the library with the teaching goals and values of the institution.-John Watts, Webster University,wattsjob@webster.edu

\section{How to teach and assess discipline- specific information literacy}

This ACRL program brought together perspectives and insights from librarian Christina Connor and psychology faculty member Nicholas Salter (both of Ramapo College of New Jersey). This standingroom-only presentation of more than 150 attendees used Psychology courses as an example to discuss faculty-librarian collaborative teaching approaches based on skill and course-level.

The main take-home points the two presenters stressed were the need to 1) create a holistic integration of information literacy within disciplines or majors, 2) 
match specific information literacy skills to select major-specific courses, and 3) establish an equal partnership among librarians and faculty members for implementation.

The presenters highlighted the benefits (and challenges) of a holistic approach to information literacy within a major. This approach treats information literacy as an important student learning outcome purposefully infused in the major rather than an assignment-driven workshop model. The case study demonstrated this tactic and gave examples for working with both introductorylevel students as well as advanced-level students in a major. Suggestions were offered on various assessment strategies: in-class activities, post-session quizzes, and a research paper rubric. Though the case study focused on one particular discipline, the presenters offered suggestions and examples using the same programmatic approach implemented in other majors.

Following the presentation, attendees discussed the challenges of engaging with faculty on programs such as this. Connor and Salter were able to offer suggestions to address these challenges in a variety of disciplines using both personal experience and professional literature. A suggested resources list was also provided for additional information. Attendees commented that the presentation provided relevant anecdotes that helped bridge the gap between standards and real life application.-Christina Connor, Ramapo College of New Jersey, cconnor@ramapo.edu; Nicholas P. Salter, Ramapo College of New Jersey,nsalter@ramapo.edu

\section{News literacy instruction}

Program moderator Lizz Zitron (Carthage College) began the Instruction Section program "All the News that's Fit to Teach: News Literacy Instruction," by introducing Stephanie Craft (University of Missouri School of Journalism). Craft presented her work on a survey that measures the news media literacy of Chicago-area teenagers. She found that three factors contribute to teens' news media literacy: 1) knowledge about how news organizations work; 2) engagement with mindful-thought processing, i.e., how much teens enjoy effortful thinking; and 3) the locus of control, or the degree to which teens feel in control of the media's influence.

She encouraged teachers to apply the survey as a diagnostic to gauge the strengths and weaknesses of a class, to emphasize the personal responsibility of news consumption, and to encourage students to ask lots of questions.

Three librarians then discussed teaching news literacy in information literacy sessions.

Laura Hibbler (College of the Holy Cross) had her students evaluate news reports from countries in the midst of violent conflict, elaborating on the importance of context. Next, Willie Miller (Indiana University-Purdue University Indianapolis) described his method of having students compare different accounts of the presidential debates in order to decode bias. Finally, Michelle Van Hoeck (California State University-Maritime) illustrated the old tradition in the newsroom of placing a story through a metal spike when it was rejected for print. She then discussed how she helped students identify the sections in print newspapers (e.g., op-eds, columns) in order to correctly identify their Web counterparts.

A lively question-and-answer session followed in which panelists were asked how they thought The Daily Show and The Colbert Report fit into news media consumption. As one panelist pointed out, "Anything that gets students engaged in news is not a bad thing."

Handouts and slides may be found at http://ala13.ala.org/node/10069._Britt McGowan, University of West Florida, bmcgowan@uwf.edu

\section{Preparing, sharing, and archiving}

The Law and Political Science Section held a program entitled "Preparing, Sharing, and Archiving: What Scholars Need to Know and How Librarians Can Help Them."

A panel of experts was gathered including Bernard Black (Northwestern University Law School and Kellogg School of Management, and Legal Scholarship Network, SSRN), Jen- 
nifer Hochschild (Harvard University and American Political Science Review editor), and Claire Stewart (Northwestern University Library).

The speakers talked with librarians about the complexity and range of scholarly communication issues as they pertain to scholars in political science and law, and strategies to use to engage these issues at their home institutions. Stewart presented information about the different types of open access (OA) publishing, including the difference between "green" and "gold" OA, and the implications of OA publishing for faculty. Black spoke energetically about the importance of SSRN to legal and political science scholars, and how preprints and working papers are integral to the database. Hochschild spoke primarily as an academic, and elaborated on how OA laws and fees differ a great deal from country to country, and how libraries can assist authors who do not have to time to upload preprints and working papers to institutional repositories and $\mathrm{OA}$ archives by offering to archive this material for them.

A general discussion followed with librarians offering solutions to the group about how to encourage more OA publishing by faculty, and ways to educate them. Ideas mentioned included universities and colleges paying author fees for OA, holding coffee talks, and having each subject librarian visit their faculty for publishing discussions.

The bibliography for this program is located at http://libguides.uwb.edu/lpss2013.— Elizabeth White, University of Georgia, elwhite1@uga.edu

\section{Mitigating disaster}

The Rare Books and Manuscripts Section sponsored the panel "History on Fire! How Libraries Mitigate Loss of the Cultural Record Due to Disaster or Destruction." The program addressed how special collections librarians mitigate the loss of unique items to disasters. Moderator Alice Shreyer (University of Chicago Library) described how libraries have tried to rebuild collections that were obliterated in disasters, including crowd-sourcing to raise funds for replacement copies of rare books, and using pre-existing inventories to establish collection development policies aimed at replacing them.

The first speaker, Russell Lewis (Chicago History Museum), addressed the work of Chicago historians, who must cope with the loss of much of Chicago's archival record in the Great Chicago Fire, which he described to place the panel in context. He also described contemporary attempts to rebuild libraries and archives after the fire through donations and bequests.

The second speaker, Valerie Harris (University of Illinois-Chicago), described ways researchers have combined new technologies and surviving pre-fire documents to bridge gaps in the record. She described a project using geographic information gleaned from books printed before the fire to map out the locations of Chicago printers, so as to virtually reconstruct the spatial layout of Chicago's printing industry.

The final speaker, E. C. Schroeder (Yale University) discussed the logistics of working with risk management to prepare for and recover from disaster. He outlined the steps involved in performing a risk assessment and in providing insurance for special collections materials. He described the Smiley map thefts as an example in which insurance was used to pay for repairs to items damaged by disaster, as well as one which prompted substantial changes in security procedures in order to prevent future disasters. Together, the speakers offered valuable insight on how to deal with the long-term ramifications of disasters.-Alexander Clark Johnston, University of Delaware, acj@udel.edu

\section{Busting out of the cubicle}

The University Libraries Section hosted the program "Busting Out of the Cubicle: Your Creative Self at Work," presented by M. J. D'Elia and Robin Bergart (both of University of Guelph-Ontario). These two librarians, founders of the Innovation Boot Camp (innovationbootcamp.wordpress.com/), led attendees through four engaging activities 
to demonstrate their central thesis that every person has the potential to be creative. As Bergart argued, "The idea of the 'lone genius' is a myth."

To frame their talk, D'Elia and Bergart introduced four different mindsets conceived by Tom Kelley and explained in his book The Ten Faces of Innovation: The Collaborator, Anthropologist, Cross-pollinator, and Experimenter. These mindsets provide perspectives that can be applied in creative thinking and problem-solving.

For example, an experimenter develops

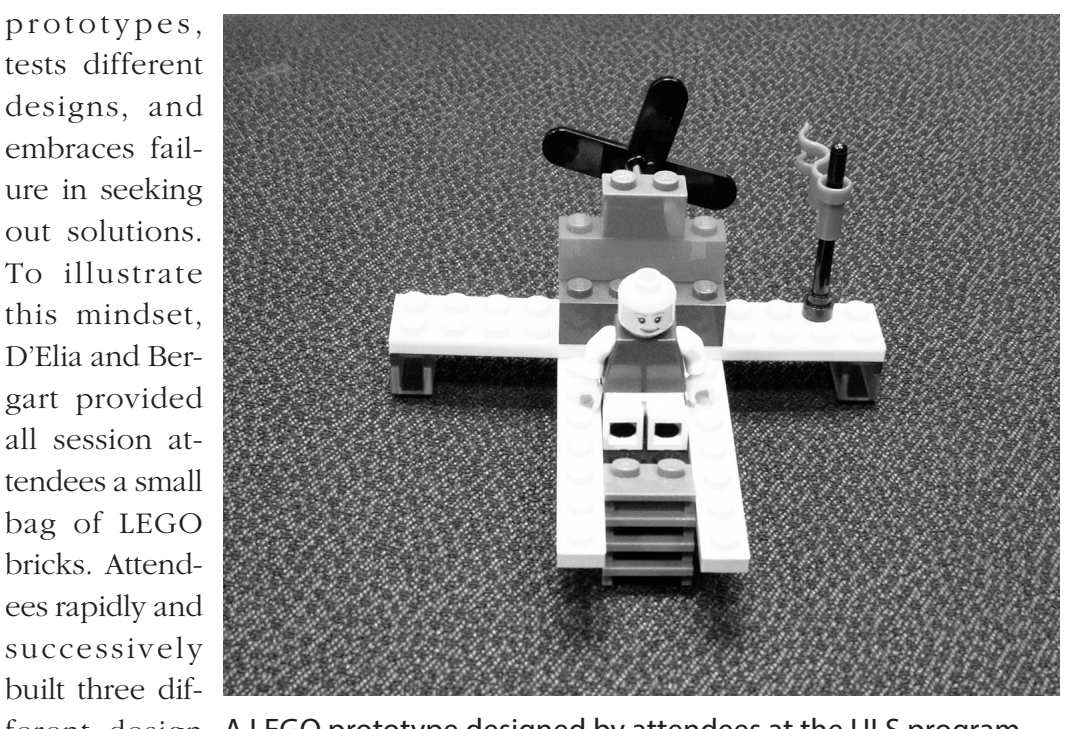

ferent design A LEGO prototype designed by attendees at the ULS program. prototypes in response to different scenarios and constraints.

D'Elia and Bergart demonstrated how each of these mindsets was applied in their own library. As cross-pollinators, they researched the customer service practices of organizations outside of the library world that are known for their service excellence, such as Zappos and Starbucks. They also conducted site visits of passport offices, retail stores, and public libraries to see what they could learn from these contexts that they in turn could apply at home.

In the end, the presenters urged attendees to expand their capacity to notice, something the four mindsets can help do. They quoted the late Steve Jobs, who once said, "Creativ- ity is just connecting things. When you ask creative people how they did something, they feel a little guilty because they didn't really do it, they just saw something."-Alec Sonsteby, Metropolitan State University, alexander. sonsteby@metrostate.edu

\section{The literary text and the library in the Digital Age}

The Literatures in English Section, Western European Studies Section, and Slavic and Eastern European Studies Section cosponsored a stimulating panel discussion on "The 
ventures for resource sharing and digital texts, such as the Center for Research Libraries and the HathiTrust.

Mandell focused on "boutique" Digital Humanities (DH) projects (such as the award-winning William Blake Archive) as means for fostering collegial librarian-faculty collaboration.

Worthey began with a theoretical overview of "How DH is made," examining it in terms of the Russian formalist approach to literary texts as large data networks. From there, he offered ideas on how librarians can work together with researchers by bringing their data organization skills to bear on DH initiatives. The subsequent discussion centered on strategies for building fruitful collaborations in the age of DH.-David Oberhelman, Oklaboma State University, d.oberhelman@okstate. edu; Colin McCaffrey, Yale University, colin. mccaffrey@yale.edu; Patricia Thurston, Yale University, patricia.thurston@yale.edu

\section{Out of the library and into the community}

The Women and Gender Studies Section program, "Out of the Library and into the Community: Academic Librarians and Community Engagement," provided an inspiring look at different ways librarians can promote democracy, information access, and distribution within their communities.

Maureen Barry (Wright State University) discussed integrating service learning into the curriculum of a semester-long course. As "librarian partners," students compile a research portfolio for a nonprofit organization. She argues that it is essential for libraries to be involved when the mission of a university includes "engaging in significant community service," enabling them to engage more meaningfully with students, faculty, and community.

Lizz Zitron (Carthage College) presented the idea that community engagement allows the library to be part of telling the campus story, enabling us to share resources with our public counterparts, while supporting our overall mission as a public institution. She empowers student workers to implement their creative ideas and engages the public at community events like a Hogwarts-themed family fun night or a "Seussathon" fundraising event where, for example, football players volunteered.

Martin Wolske (University of Illinois) highlighted service learning from his perspective as a faculty member in the School of Library and Information Science, educating future librarians. He advocates community inquiry-a "person-oriented" rather than "thing-oriented" approach — engaging the community in its own needs assessment rather than imposing solutions (often technology) as the only answer. When the answer does include technology, he emphasizes community involvement in shaping that technology. The community includes the university, with all participants learning, researching, and teaching together. He advocates a sustainable approach, assessing why these places of need exist and how our choices help to create them.

The program was moderated by $\mathrm{Pa}$ mela Salela (University of Illinois-Springfield) and cosponsored by the Education and Behavioral Sciences Section and Social Responsibility Round Table._Laura Bonella, Kansas State University, laurab@ k-state.edu $\mathrm{n}$

\section{Upcoming ACRL e-Learning}

ACRL is offering a variety of online seminars and Webcasts this fall. Upcoming topics include:

Helping Non Innovators through Innovation: Managing Change (Online Seminar: September 16-October 6, 2013)

Applying the Standards for Libraries in Higher Education-Designing Assessments (Webcast: October 2, 2013)

The Publishing Rollercoaster: Writers Sound Off (Webcast: October 9, 2013)

Visit the ACRL e-Learning Web site at www. ala.org/acrl/onlinelearning for details 